\title{
Characterization of Microcracks in the Cuticle of Developing Sweet Cherry Fruit
}

\author{
Stefanie Peschel and Moritz Knoche ${ }^{1}$ \\ Institute for Agronomy and Crop Science, Department of Horticulture, Martin-Luther-University of \\ Halle-Wittenberg, D-06099 Halle (Saale), Germany
}

\begin{abstract}
AdDitional INDEX words. strain, cuticle, cracking, fruit growth, Prunus avium
Abstract. Frequency and distribution of microcracks in the cuticular membrane (CM) were monitored in cheek, suture, pedicel cavity and stylar regions of developing sweet cherry (Prunus avium L.) fruit using fluorescence microscopy following infiltration with a fluorescence tracer $(1$ to $2 \mathrm{~min}$ in $0.1 \% \mathrm{w} / \mathrm{v}$ acridine orange containing $50 \mathrm{~mm}$ citric acid and 0.1\% Silwet L-77, pH 6.5). These microcracks were limited to the cuticle, did not extend into the pericarp and were only detected by microscopy. Fruit mass and surface area increased in a sigmoidal pattern with time between 16 days after full bloom (DAFB) and maturity. The increase in frequency of fruit with microcracks paralleled the increase in fruit mass. During early development (up to 43 DAFB) the CM of 'Sam' fruit remained intact. However, by 57 DAFB essentially all 'Sam' fruit had microcracks in the pedicel cavity and $\approx 25 \%$ in the suture region with little change thereafter. At maturity percentage of 'Sam' fruit with microcracks in cheek, suture, pedicel cavity and stylar end region averaged $23 \%, 25 \%, 100 \%$, and $63 \%$, respectively. Similar data were obtained for 'Hedelfinger' $(70 \%$ and $100 \%$ for cheek and pedicel cavity, respectively), 'Kordia' ( $80 \%$ and $100 \%)$ and 'Van' $(100 \%$ and $100 \%)$. Generally, microcracks were most severe in pedicel cavity and stylar end region. Most of the first detectable microcracks formed above periclinal walls of epidermal cells perpendicular to their longest axis (72\% and $92 \%$ in cheek and stylar regions, respectively). The other microcracks formed above the anticlinal walls were mostly oriented in the direction of the underlying cell wall. There was no difference in projected surface area, length/width ratio or orientation among epidermal cells below, adjacent to or distant from the first detectable microcracks in the CM. However, as length of microcracks increased the projected surface area of cells underlying cracks increased suggesting strain induced upon cracking of the CM. Permeability of excised exocarp segments in osmotic water uptake was positively correlated with number of stomata and number of microcracks in the CM. From our results we suggest that strain of the epidermal system during stage III of fruit growth is a factor in "microcracking" of the CM that may predispose fruit to subsequent rain-induced cracking.
\end{abstract}

Rain-cracking of fruit is a limitation in production of sweet cherry fruit worldwide. Cracking is thought to result from increased turgor caused by water uptake into the fruit (Andersen and Richardson, 1982; Considine and Kriedemann, 1972).

Macroscopic fruit cracking is preceded by development of minute fractures in the cuticular membrane $(\mathrm{CM})$ that initially traverse only the CM and that do not extend into epi- and hypodermal cell layers and the mesocarp (Glenn and Poovaiah, 1989). We refer to these initial fractures of the $\mathrm{CM}$ as microcracks, since they are not detected without the aid of a microscope (Glenn and Poovaiah, 1989). These microcracks are often observed on immature and mature sweet cherry fruit (Glenn and Poovaiah, 1989; Sekse, 1995) and frequency of microcracks generally increases during development (Knoche et al., 2001).

Development of microcracks may be an early event in macroscopic fruit cracking, since 1) the $\mathrm{CM}$ is the rate limiting barrier to water transport across the fruit surface (Beyer and Knoche, 2002; Knoche et al., 2000) and water uptake was increased in fruit having microcracks (Glenn and Poovaiah, 1989), and 2) macroscopic cracks were reported to develop along microcracks and progress along their length (Glenn and Poovaiah, 1989).

Received for publication 2 Mar. 2005. Accepted for publication 7 May 2005. This research was funded in part by grants from the Deutsche Forschungsgemeinschaft, the Saale Obst Erzeuger- und Absatzgenossenschaft and the Gisela Foundation. We thank Kurt Ehm, Wolfgang Meyer, and Erhard Sonnenkalb for providing fruit samples; Matthias Hinz and Evelyn and Ruth Richter for technical assistance; and John Bukovac, Greg Lang, and Peter Petracek for critical comments on an earlier version of this manuscript.

1To whom reprint request should be addressed. E-mail address: moritz. knoche@landw.uni-halle.de
Up to now the mechanistic basis of formation of microcracks in the CM is unknown. Knoche et al. (2004) demonstrated that the CM is markedly strained particularly during stage III or "final swell" of fruit development. This stage is characterized by a rapid increase in fruit mass and hence surface area, while CM mass on a per fruit basis remains constant. The strain of the $\mathrm{CM}$ resulting from fruit surface expansion in the absence of CM deposition is expected to cause stress and stress induced failure is a basic concept in material science.

To gain a better understanding of the mechanism of formation of microcracks in the CM, analysis of the fracture pattern may be helpful. If strain was an important factor, crack formation should be related to fruit surface expansion and development of strain in the CM. Furthermore, microcracks would be expected to be preferentially oriented relative to the primary axis of strain. Finally, formation of microcracks in the CM should result in an increase in strain of the underlying epidermal cells. To test this hypothesis, we investigated the occurrence, distribution and characteristics of microcracks in the CM of developing sweet cherry fruit. We focused on developing sweet cherry fruit, since cracking susceptibility increased markedly towards maturity (Christensen, 1996).

\section{Materials and Methods}

Plant material. Frequency and distribution of microcracks in the CM of developing sweet cherry fruit ('Hedelfinger', 'Kordia', 'Sam', and 'Van'; all grafted on P. avium 'Alkavo' rootstocks planted in 1989) CM were monitored. Fruit were sampled at weekly intervals between 16 and 92 DAFB ('Hedelfinger'), 16 and 85 DAFB ('Kordia'), 16 and 78 DAFB ('Sam'), and 16 and 
71 DAFB ('Van') in a commercial orchard located near Eisleben, Germany (lat. $51^{\circ} 31^{\prime} \mathrm{N}$, long. $11^{\circ} 44^{\prime} \mathrm{E}$ ) in 2000 . These fruit originated from a minimum of ten representative trees per cultivar and sampling time. Fruit were selected for uniformity and freedom of visual defects, pooled per cultivar, transferred to the laboratory and held overnight at $5^{\circ} \mathrm{C}$. Subsamples were formed and used in our earlier study for determining fruit mass, osmotic potential, strain of CM, and mass of CM per unit fruit surface area (Knoche et al., 2004) and in the present study for monitoring frequency and distribution of microcracks in the CM. Sweet cherry fruit of 'Burlat' (grafted on P. avium 'Alkavo') were obtained from a commercial orchard at Höhnstedt, Germany (lat. $51^{\circ} 30^{\prime} \mathrm{N}$, long. $11^{\circ} 44^{\prime} \mathrm{E}$ ) in the 2003 growing season and used for characterizing microcracks. Trees were cultivated according to current regulations for integrated fruit production (Landespflanzenschutzamt Sachsen-Anhalt, 2000, 2003).

MASS AND SURFACE AREA OF DEVELOPING FRUIT. Data for mass of developing 'Hedelfinger', 'Kordia', 'Sam', and 'Van' fruit were reproduced and redrawn with permission from Knoche et al., Physiol. Plant. 120:667-677, 2004. Fruit surface area was calculated from fruit mass assuming a spherical shape of the fruit and a density of $1000 \mathrm{~kg} \cdot \mathrm{m}^{-3}$ as a first approximation.
MONITORING MICROCRACKS IN DEVELOPING FRUIT. Following equilibration at room temperature, fruit were incubated in a solution containing the fluorescent tracer acridine orange at $0.1 \%$ and a silicone surfactant [surface tension, $21 \mathrm{mN} \cdot \mathrm{m}^{-1}$ at $0.1 \%$ (Silwet L-77; Witco, Düsseldorf, Germany) (Knoche et al., 1991)] in $50 \mathrm{~mm}$ citric acid buffer at $\mathrm{pH}$ 6.5. Solutions containing Silwet L-77 infiltrated microcracks in the CM. After 1 to $2 \mathrm{~min}$, fruit were removed from solution and blotted dry using tissue paper. Exocarp segments (ES) comprising CM, epidermis, hypodermis and some cell layers of mesocarp tissue were excised by razor blade from cheek, suture, pedicel cavity and stylar regions ('Sam'; 22 to 78 DAFB) and from cheek and stylar regions ('Hedelfinger', 22 to 92 DAFB; 'Kordia', 22 to 85 DAFB; 'Van', 22 to 71 DAFB). ES were transferred to the stage of a fluorescence microscope (model BX-60; Olympus, Hamburg, Germany) and viewed at $\times 100(330-385 \mathrm{~nm}$ excitation wave length, $420 \mathrm{~nm}$ emission wave length; Olympus filter module U-MWU). Ten randomly selected areas $\left(621 \times 468 \mu \mathrm{m}^{2}\right)$ per ES of a total of ten fruit per sampling date, region and cultivar were inspected for microcracks in the CM. Severity of microcracks was quantified using the following rating scheme (Fig. 1): score 0 , surface without cracks (Fig. 1A); score 1, single microcrack

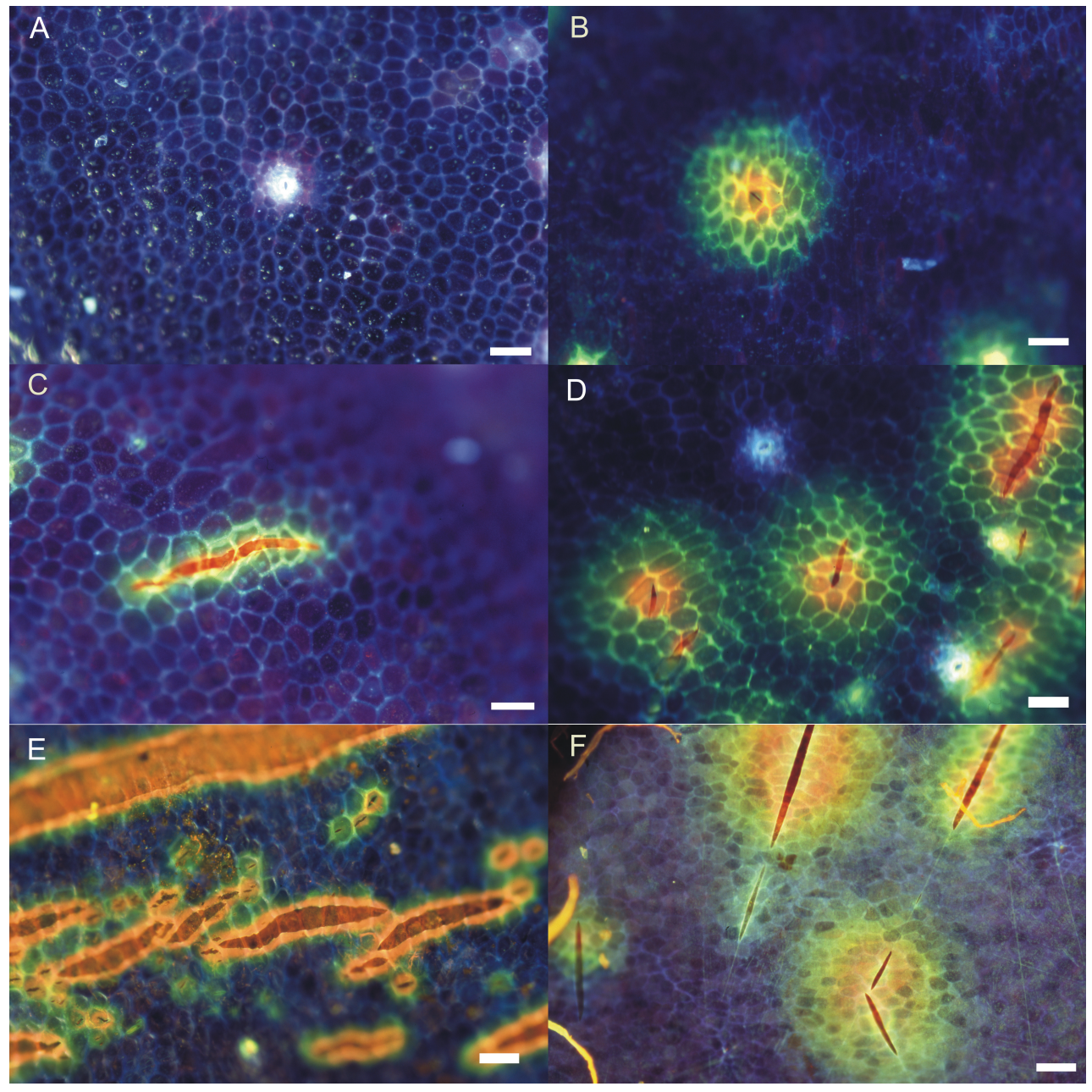

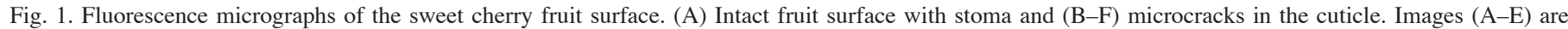

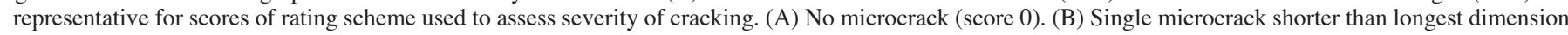

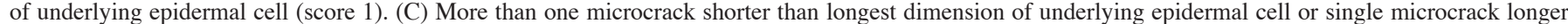

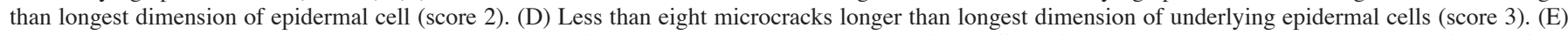

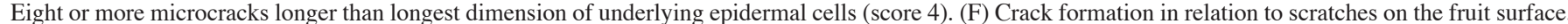
Images were taken at $\times 100$. Scale bar $100 \mu \mathrm{m}$. 
shorter than longest dimension of the underlying epidermal cell (Fig. 1B); score 2, more than one microcrack shorter than longest dimension of underlying epidermal cell or single microcrack longer than longest dimension of the epidermal cell (Fig. 1C); score 3 , less than eight microcracks longer than longest dimension of underlying epidermal cells (Fig. 1D); score 4, eight or more microcracks longer than longest dimension of underlying epidermal cells (Fig. 1E).

Characterizing initial Microcracks in the CM. Digitized images of short microcracks (rating score 1$)$ in cheek $(n=60)$ and stylar end region $(n=60)$ of a minimum of 40 macroscopically sound 'Burlat' fruit were prepared following infiltration as described above using a video camera (Hitachi Denshi Europa $\mathrm{GmbH}$, Rodgau, Germany) fitted to the fluorescence scope. The microcracks selected were shorter than the longest dimension of the underlying epidermal cell. The following characteristics were determined by image analysis (analySIS 3.0; Soft Imaging System $\mathrm{GmbH}$, Münster, Germany): Location of microcrack (above the anticlinal vs. periclinal cell wall in cheek and stylar regions); orientation of microcrack above periclinal cell wall [angle formed by length axis of crack and length axis of underlying epidermal cell (stylar end and cheek region), angle formed by length axis through crack and stylar/pedicel axis (cheek) or radial axis through stylar scar (stylar scar region)]; orientation of microcrack above anticlinal cell wall (angle formed by length axis of crack and anticlinal cell wall); dimension of microcrack and underlying cell (area, length, width, length/width ratio). Epidermal cells adjacent to or distant from the crack (mean distance $200 \mu \mathrm{m}$ from crack) served as comparison. Frequency distributions were established for orientation of microcracks and epidermal cells using nine orientation classes covering a range in orientation from -90 to $90^{\circ}$ relative to the respective reference axis and a class width of $20^{\circ}$ (Fig. 4A-D; Fig. $5 \mathrm{C}$ and D). For frequency distributions of projected surface area and length/width ratio of epidermal cells the number of classes was 10 . The ranges covered were 0 to $6000 \mu \mathrm{m}^{2}$ and 0 to 5 at class width of $600 \mu \mathrm{m}^{2}$ and 0.5 for projected surface area and length/width ratio, respectively (Fig. $5 \mathrm{~A}$ and $\mathrm{B})$. The percentage of observations in individual classes was established and plotted against the mean of the respective class (Figs. 4 and 5).

WATER PERMEABILITY OF EXOCARP SEGMENTS. Effects of microcracks on the osmotic water permeability coefficient $\left(\mathrm{P}_{\mathrm{f}}\right)$ were determined using the procedure established previously (Beyer and Knoche, 2002). The $P_{f}$ is also referred to as filtration permeability or osmotic water permeability $\mathrm{P}_{\text {os }}$ (House 1974; Schönherr, 1982) or conductance for water uptake $g_{\text {uptake }}$ (Beyer and Knoche, 2002). Briefly, exocarp segments free of defects by visual inspection were excised from the cheek of mature 'Sam' sweet cherry fruit and mounted on stainless steel diffusion cells using a high vacuum grease. Diffusion cells were filled with a receiver solution containing polyethylene glycol (PEG 6000; Merck Eurolab GmbH, Darmstadt, Germany) via a sampling port in the bottom. Osmolality of the receiver solution as determined by vapor pressure osmometry (model 5520; Wescor, Logan, Utah) was $1140 \mathrm{mmol} \cdot \mathrm{kg}^{-1}$ (equivalent osmotic pressure -2.83 $\mathrm{MPa}$ ). This osmolality corresponded to the osmotic pressure of juice extracted from a representative sample of mature 'Sam' sweet cherry fruit. Diffusion cells were tape sealed (tesa Film; tesa-Werke, Offenburg, Germany). Experiments were initiated by weighing diffusion cells and applying $\approx 0.15 \mathrm{~mL}$ of deionized water as the donor solution to the exocarp segment. Donor solutions

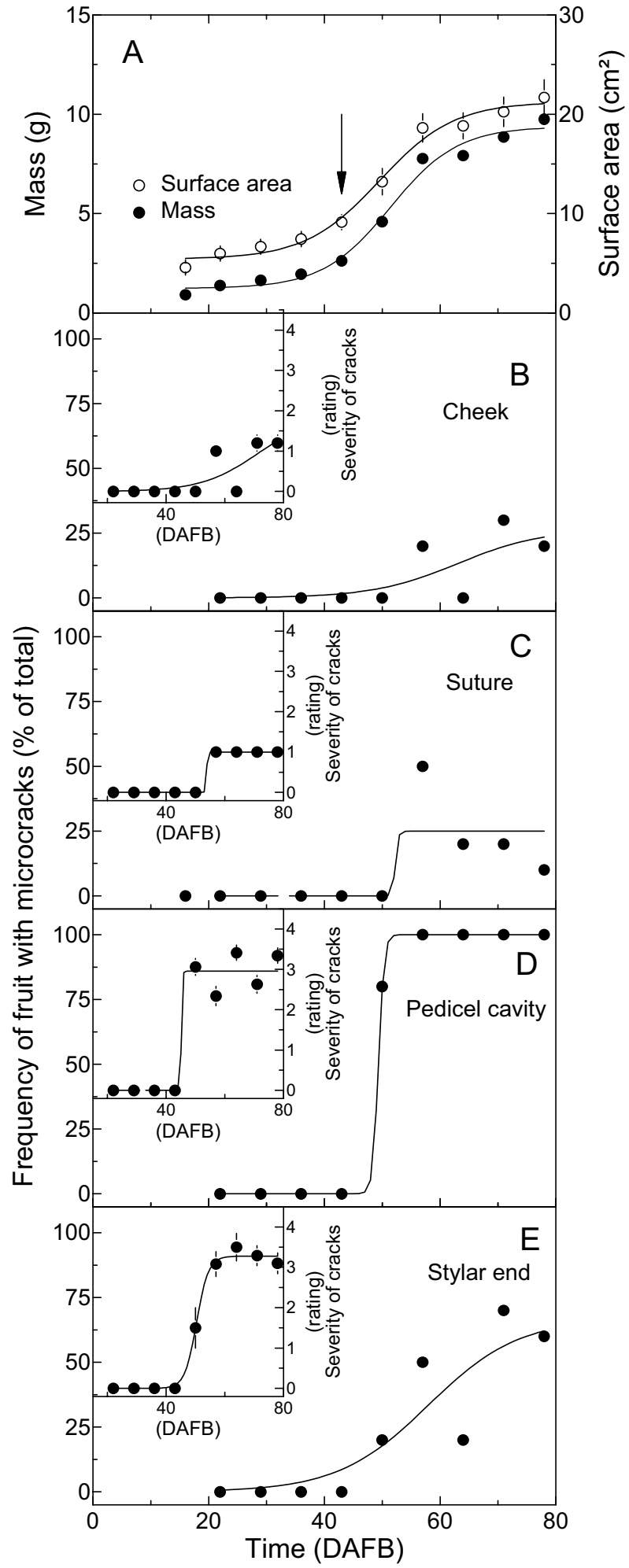

Fig. 2. Time course of change in fruit mass, calculated fruit surface area (A) and frequency of 'Sam' sweet cherry fruit with microcracks in the cuticle (B-E). Microcracks in (B) cheek, (C) suture, (D) pedicel cavity, and (E) stylar end regions. Insets in B-E: Time course of change in severity of microcracks. For representative images of rating scores, see Fig. 1A-E. Scale of time axis in days after full bloom (DAFB). Fruit surface area was calculated from fruit mass assuming a spherical shape of the fruit and a density of $1000 \mathrm{~kg} \cdot \mathrm{m}^{-3}$. Arrow in A indicates onset of elastic strain in the cuticle (Knoche et al., 2004). Figure $2 \mathrm{~A}$ reproduced with permission from Knoche et al. (2004). 


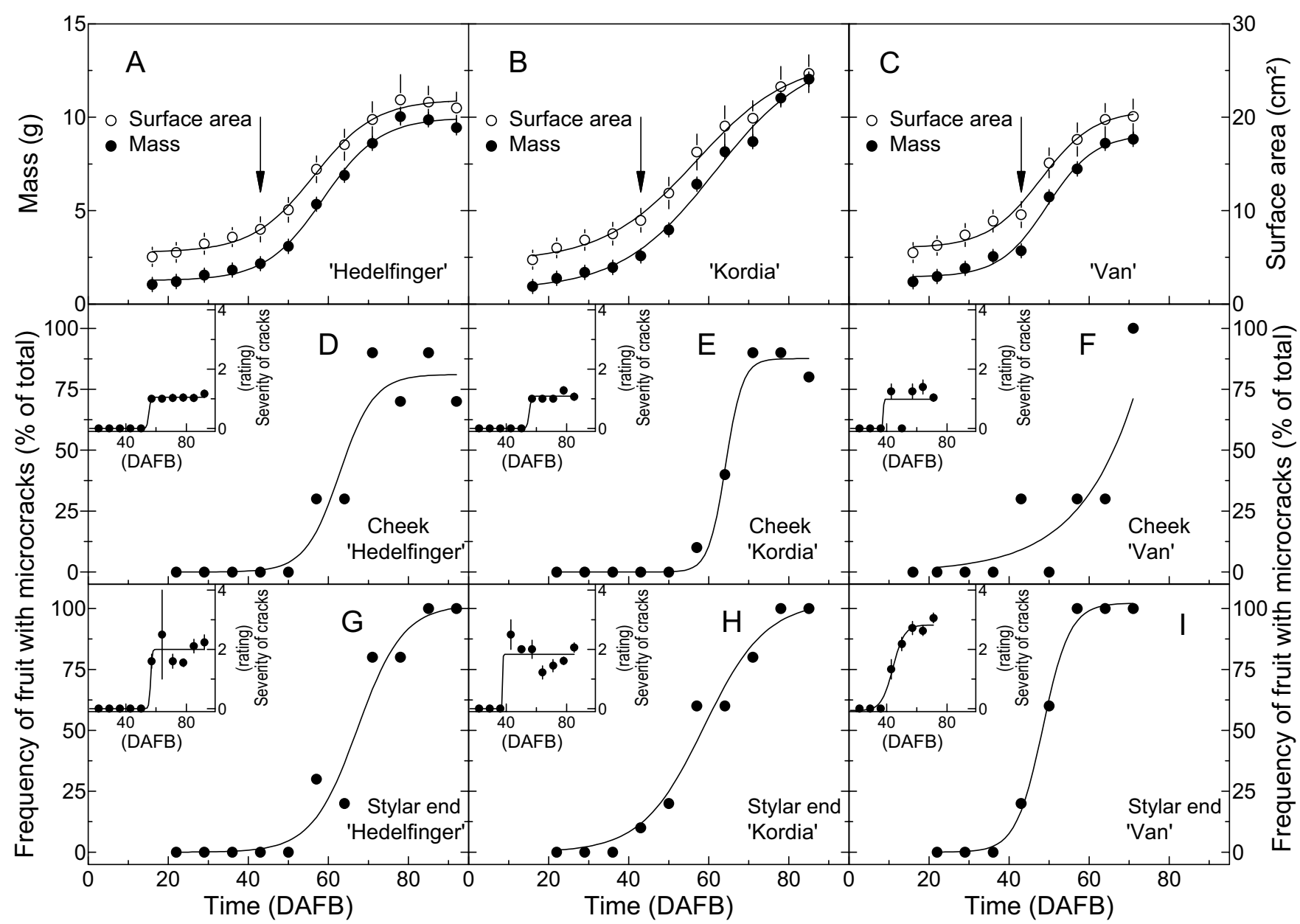

Fig. 3. Time course of change in fruit mass and calculated fruit surface area (A-C), in frequency of fruit with microcracks and in severity of microcracks (Insets) in cheek (D-F), and stylar end regions (G-I) of developing 'Hedelfinger' (A, D, G), 'Kordia' (B, E, H), and 'Van' (C, F, I) sweet cherry fruit. For representative images of rating scores, see Fig. 1A-E. Scale of time axis in days after full bloom (DAFB). Fruit surface area was calculated from fruit mass assuming a spherical shape of the fruit and a density of $1000 \mathrm{~kg} \cdot \mathrm{m}^{-3}$. Arrows in A, B, C indicate onset of elastic strain in the cuticle (Knoche et al., 2004). Figure 3A-C redrawn with permission from Knoche et al. (2004).

were removed at 1,2,3, and $4 \mathrm{~h}$ after droplet application, diffusion cells were weighed, and donor solutions were reapplied. The osmotic water permeability coefficient $\left(\mathrm{P}_{\mathrm{f}}\right.$ in $\left.\mathrm{m} \cdot \mathrm{s}^{-1}\right)$ was calculated from flow rates $\left(\mathrm{F}\right.$ in $\left.\mathrm{kg} \cdot \mathrm{s}^{-1}\right)$ of water across the exposed segment area $(\mathrm{A}$ in $\mathrm{mPa}$ ) using the gradient in water potential between the water donor and the PEG receiver solution as the driving force $(\Delta \Psi$ in megapascals) according to Eq. [1]:

$\mathrm{F}=\mathrm{A} \times \mathrm{J} \times \rho=\mathrm{A} \times \mathrm{P}_{\mathrm{f}} \times \frac{\mathrm{V}_{\mathrm{w}}}{\mathrm{RT}} \times \rho \times \Delta \Psi$

In this equation (in cubic meters per mole) represents the partial molar volume of water, $\rho\left(\right.$ in $\left.\mathrm{kg} \cdot \mathrm{m}^{-3}\right)$ the density of water, $\mathrm{R}$ (in $\mathrm{m}^{3} \mathrm{~Pa} \mathrm{~mol}^{-1} \mathrm{~K}^{-1}$ ) the universal gas constant and $\mathrm{T}$ (in $\mathrm{K}$ ) the absolute temperature (Nobel, 1999). F was obtained from the slope of a linear regression line fitted through a plot of mass of diffusion cells vs. time ( $\mathrm{n}=152$, overall mean $r^{2}=0.95 \pm 0.08$ ). Following transport experiments, $\approx 0.15 \mathrm{~mL}$ of a $0.1 \%$ acridine orange solution containing $0.1 \%$ Silwet L- 77 was applied to the surface of the ES to infiltrate microcracks and stomata. The dye solution was removed after 1-2 min by carefully blotting. Numbers of stomata and short (microcracks shorter than longest dimension of the underlying epidermal cell) and long microcracks (longer than longest dimension of the underlying epidermal cell) were determined by fluorescence microscopy on an individual ES basis. Since CM, stomata, and microcracks represent parallel pathways for water uptake through the fruit surface, multiple linear regression analysis was used to express $P_{f}$ as a function of the number of stomata and of small and large microcracks per ES $(n=152)$. The parameter estimates obtained thus represent estimates of the $\mathrm{P}_{\mathrm{f}}$ of stomata, small and large cracks, the intercept term the $\mathrm{P}_{\mathrm{f}}$ of the $\mathrm{CM}$ between stomata and microcracks.

Terminology and Data analysis. Our study focused on microscopic cracks in the $\mathrm{CM}$ that are referred to as microcracks. These microcracks are limited to the CM, do not extend into the epi- and hypodermal cell layers or the mesocarp of the fruit, and are only detected by microscopy (Glenn and Poovaiah, 1989). Fruit having microcracks in the CM by fluorescence microscopy are termed "cracked" fruit. Thus, these "cracked" fruit would be classified as intact based on macroscopic inspection.

Frequency of cracked fruit (score $>0$ ) was calculated as percentage of total number of fruit inspected, and severity of cracks as the average of rating scores $>0$. Time course data of change in severity of microcracks, and of osmotic water uptake are presented as means and standard errors of means. Nonlinear (Proc. NLIN, logistic model) and linear regression analysis (Proc. REG) was carried out using SAS (version 8; SAS Institute, Cary, N.C.). 

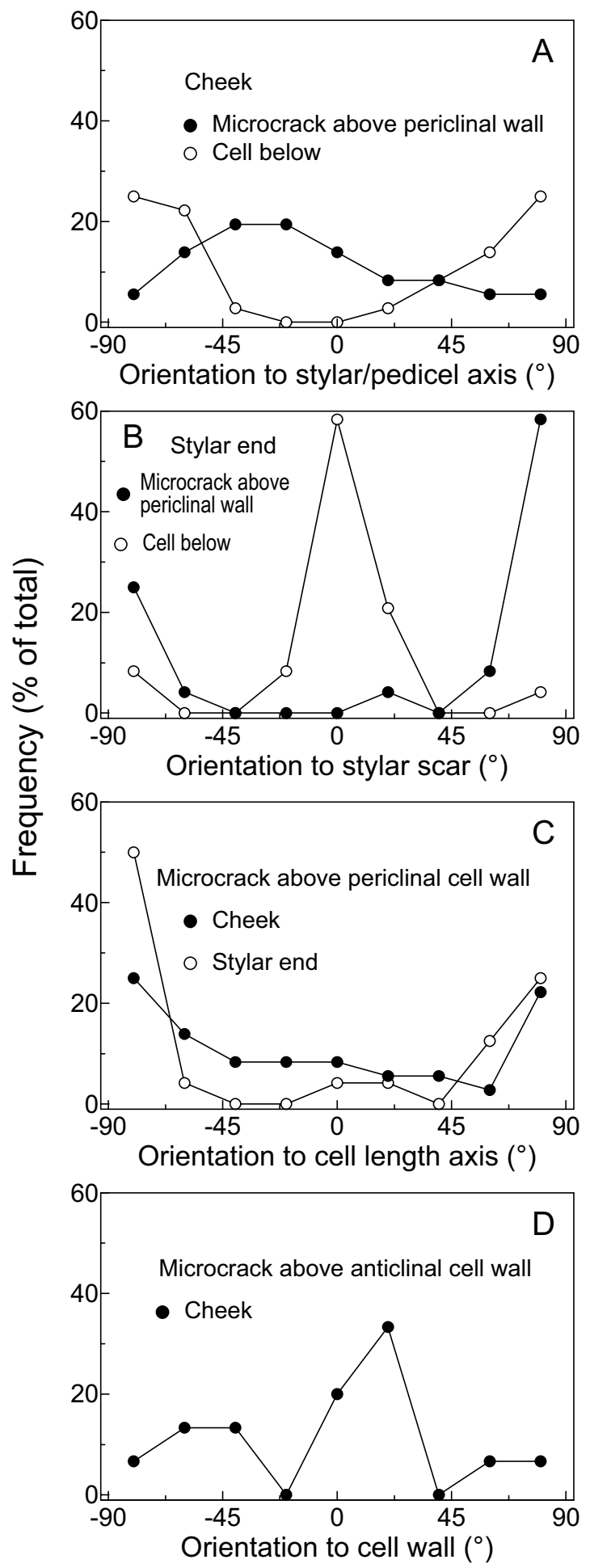

Fig. 4. Frequency distribution of orientation of short microcracks (rating score 1 $=$ shorter than longest dimension of underlying epidermal cell) and underlying epidermal cells in 'Burlat' sweet cherry fruit. (A, B) Orientation of microcracks above periclinal cell walls and of underlying epidermal cell in (A) cheek region relative to the stylar/pedicel axis or (B) stylar end region relative to the radial axis through the stylar scar. (C) Orientation of microcracks above periclinal cell walls in cheek and stylar region relative to the length axis of the underlying epidermal cell. (D) Orientation of microcracks above anticlinal cell walls relative to that of the underlying cell wall.
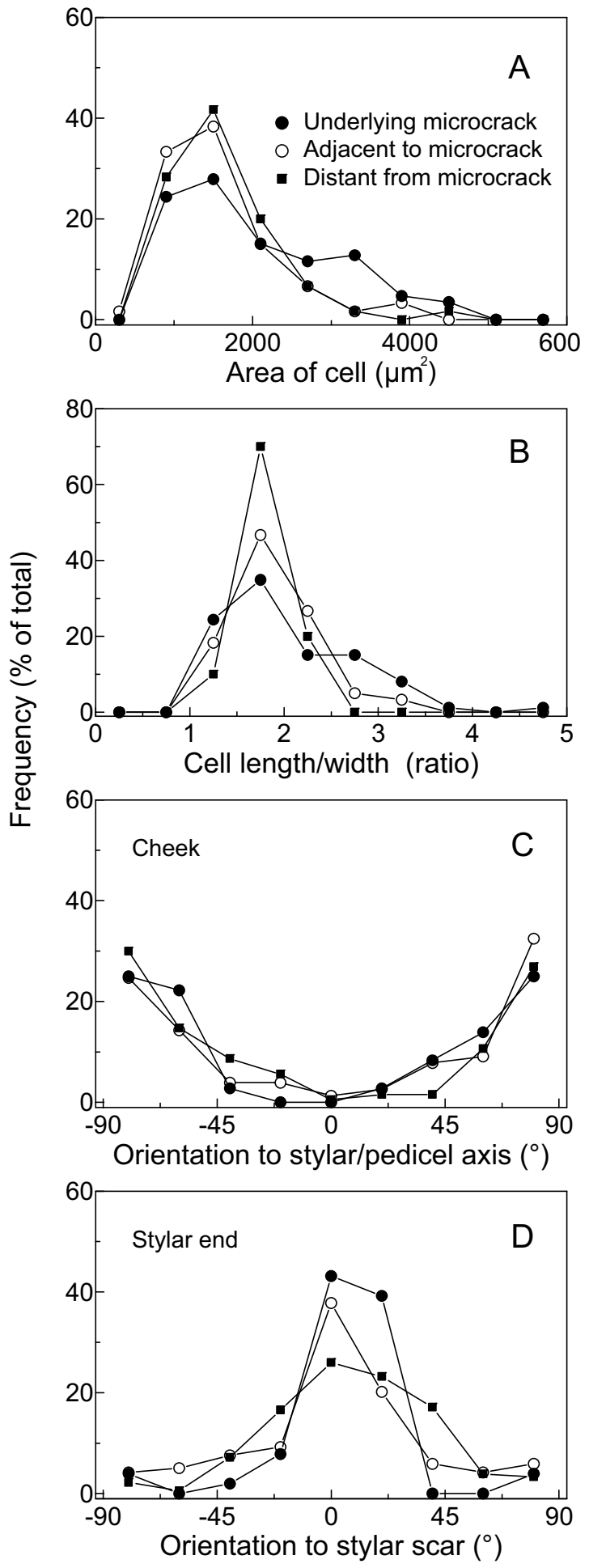

Fig. 5. Frequency distributions of various characteristics of epidermal cells below, adjacent to, or distant (mean distance $200 \mu \mathrm{m}$ ) from microcrack. (A) Projected surface area. (B) Length/width ratio. (C, D) Orientation of epidermal cells in (C) the cheek region relative to the stylar/pedicel axis and (D) the stylar end region relative to the radial axis through the stylar scar of mature 'Burlat' sweet cherry fruit. 


\section{Results}

Mass and surface area of 'Sam' sweet cherry fruit increased in a sigmoidal pattern with time [Fig. 2A (for regression equations see Knoche et al., 2004)]. The increase in fruit mass was paralleled by a corresponding increase in frequency of fruit with microcracks in the CM (Fig. 2B-E). The CM remained crack-free in all regions up to 43 DAFB (end of stage II; Fig. 2). Thereafter, percentage of fruit with microcracks increased and averaged $23 \%, 25 \%, 100 \%$, and $62 \%$ in cheek, suture, pedicel cavity, and stylar region at maturity, respectively (Fig. 2). The steepest increase occurred in the pedicel cavity region where all 'Sam' fruit developed microcracks within a 14-d period between 43 and 57 DAFB (Fig. 2D). Compared to the pedicel cavity region, the change in frequency with time was more variable in cheek, suture, and stylar regions (Fig. 2 B, C, and E). Microcracks in the CM of 'Sam' fruit were most severe in the pedicel cavity and stylar regions (mean rating scores $3.3 \pm 0.1$ and $3.1 \pm 0.3$, respectively), and least severe in cheek and suture regions (mean rating scores $1.2 \pm 0.2$ and $1.0 \pm 0.0$, respectively; Fig. 2 insets). The increase in severity of microcracks with time paralleled the increase in frequency of fruit with microcracks.

Qualitative data similar to 'Sam' were obtained for 'Hedelfinger', 'Kordia', and 'Van' (Fig. 3). There were no microcracks in the $\mathrm{CM}$ up to $\approx 43 \mathrm{DAFB}$ (end of stage II) followed by a rapid increase during stage III (Fig. 3). Quantitatively, a higher percentage of mature 'Hedelfinger', 'Kordia', and 'Van' fruit had microcracks in the cheek region as compared with that of 'Sam'. There was little difference between cultivars in percentage of fruit with microcracks in the stylar region. Across cultivars, microcracks in the stylar region were generally more severe than in the cheek region (Fig. 3). Percentage of fruit with microcracks and severity of cracks were positively related $[r=0.75(P \leq 0.001)$; pooled data for cultivars and regions].

To explore early development of microcracks in the CM we focused on characteristics of short microcracks (rating score 1) and underlying, adjacent, or distant epidermal cells in cheek and stylar region of 'Burlat' fruit. The area of these short microcracks was markedly smaller (median area of cracks: 30.6 and 108.5 $\mu \mathrm{m}^{2}$ equivalent to $2.1 \%$ and $6.4 \%$ of the projected surface area of underlying cell in cheek and stylar regions, respectively) than the projected surface area of underlying epidermal cells, indicating that these cracks were detected shortly after formation. Most (72\% and $92 \%$ in the cheek and stylar regions, respectively) of these microcracks formed above periclinal walls of epidermal cells; the remaining $28 \%$ and $8 \%$ above anticlinal cell walls, respectively.

Microcracks and underlying epidermal cells were preferentially oriented in the cheek and, even more so, in the stylar end region (Fig. $4 \mathrm{~A}$ and $\mathrm{B}$ ). In the cheek region, microcracks were often oriented parallel to the stylar/pedicel axis, but underlying epidermal cells perpendicular to the stylar/pedicel axis (Fig. 4A). For the stylar region, crack orientation was tangential relative to the stylar scar, but that of cells below cracks was dominantly radial (Fig. 4B). For both regions, most microcracks formed perpendicular to the longitudinal axis of the underlying epidermal cell (Fig. 4C). Cracks above anticlinal cell walls were mostly parallel to the wall (Fig. 4D; data for cheek).

Projected surface areas of epidermal cells were highly variable. The projected surface area of epidermal cells below (1454 \pm 89 $\mu \mathrm{m}^{2}$ ) these short microcracks (score 1) did not differ statistically from those adjacent to $\left(1424 \pm 74 \mu \mathrm{m}^{2}\right)$ or distant from the crack $\left(1423 \pm 65 \mu \mathrm{m}^{2}\right.$; Fig. 5A). However, when longer microcracks that extended beyond the dimensions of the underlying cell were included in the analysis, a weak, positive, and significant relationship between the projected surface area of epidermal cells below the crack and crack length was obtained (Fig. 6). The slope of the regression line that may be interpreted as the increase in projected surface area of the epidermal cell per unit crack length was higher for cells below the crack than for those adjacent to or distant from the crack. If the strain of epidermal cells underlying longer microcracks in the CM increased in response to crack formation, we would expect these cells to have a larger projected surface area than those adjacent to the crack. This was the case, since the difference in projected surface area (Y in $\mu \mathrm{m}^{2}$ ) of epidermal cells below minus that of cells adjacent to the crack was positively related to crack length and extrapolated to zero [X in $\mu \mathrm{m}$; regression equation: $\mathrm{Y}=2.4( \pm 0.4) \mathrm{X} ; r^{2}=0.28$ $(P \leq 0.001)]$. There was little difference in length/width ratios of epidermal cells below the crack $(2.0 \pm 0.1)$, neighboring $(1.9 \pm$ $0.1)$, or distant cells $(1.8 \pm 0.0$; Fig. 5B). Furthermore, there was no difference in orientation of epidermal cells below, adjacent to or distant from cracks (Fig. $5 \mathrm{C}$ and D).

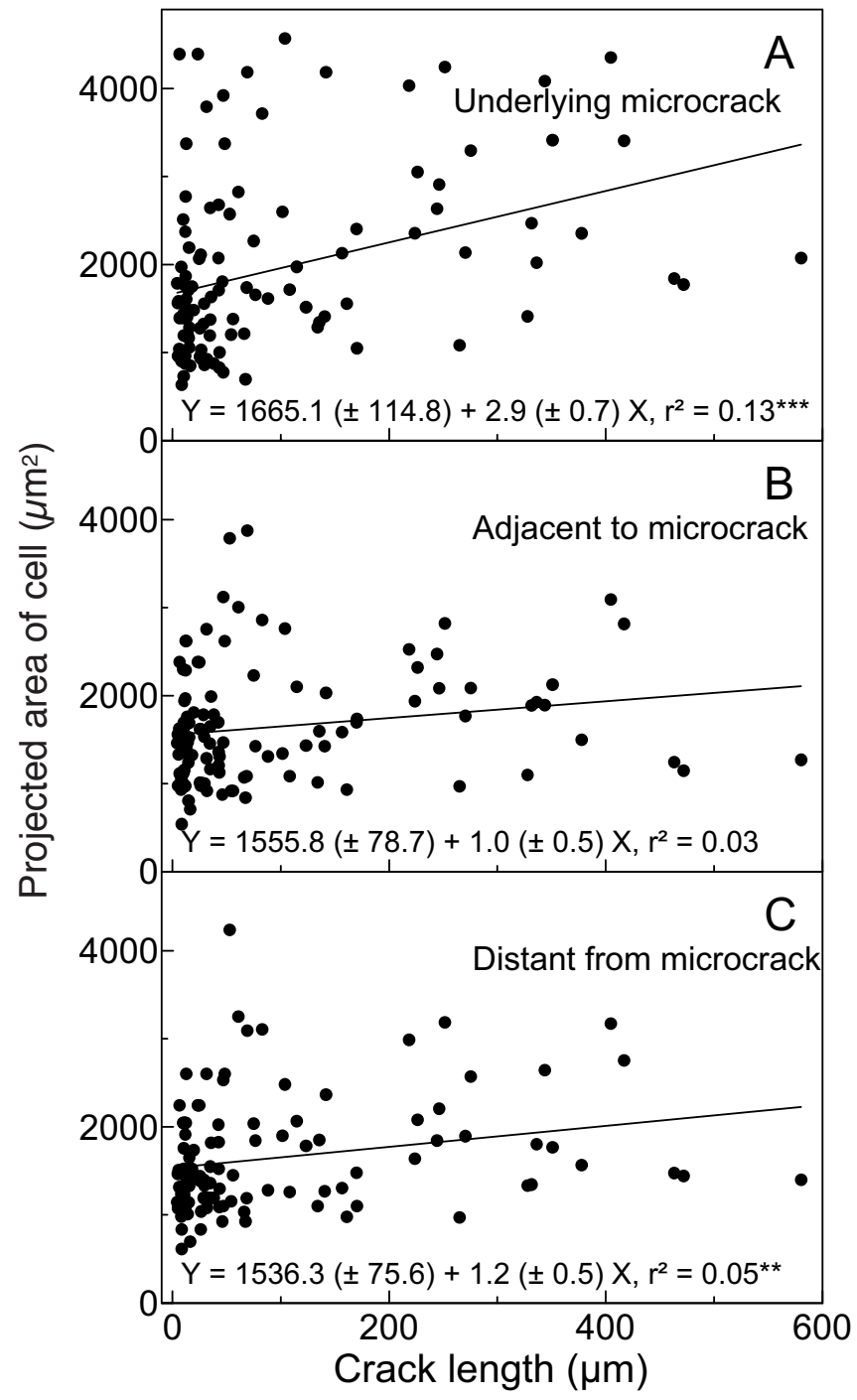

Fig. 6. Relationship between length of microcracks in the cuticle of mature 'Burlat' sweet cherry fruit and the projected surface area of epidermal cell underlying microcracks (A), adjacent to microcracks (B), or distant from microcracks (C; mean distance $200 \mu \mathrm{m}$ ). Data points represent individual observations. 
Water uptake through excised exocarp segments of mature 'Sam' sweet cherry fruit increased linearly with time (Fig. 7). Osmotic water permeability was related positively to frequency of microcracks and number of stomata (Table 1). When expressing osmotic water permeability of exocarp segments as a function of the number of stomata, of shorter and longer microcracks per segment using multiple linear regression analysis, the regression coefficients obtained represent estimates of permeability of an individual stoma, short or long microcrack, respectively, the intercept term an estimate of the intact $\mathrm{CM}$ between stomata and cracks. Permeability of a long microcrack in the CM exceeded that of an average stoma by almost one order of magnitude. The permeability of a short microcrack in osmotic water uptake, however, was markedly smaller (18\% of the permeability of an individual stoma) and not significantly different from zero at the crack densities encountered in these experiments $(P=0.07)$.

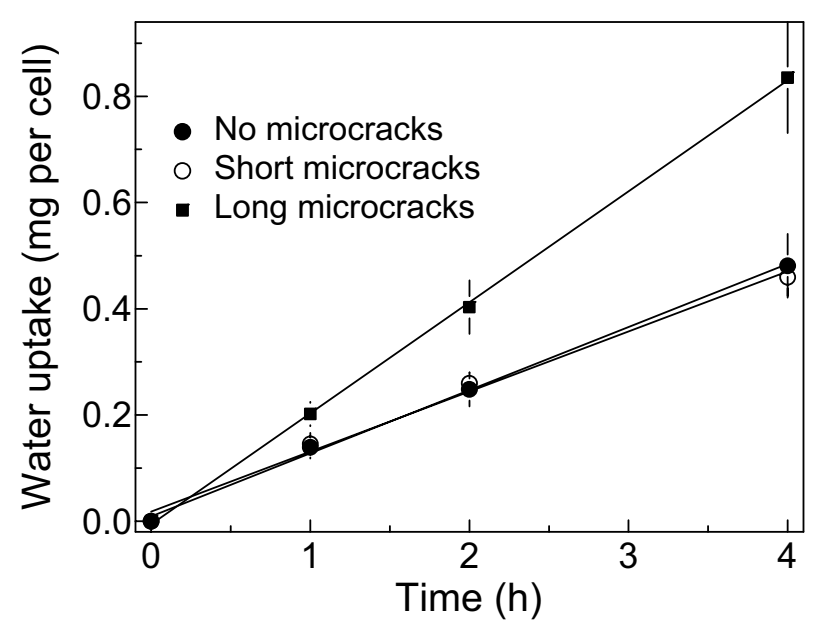

Fig. 7. Time course of water uptake through excised exocarp (ES) segments of mature 'Sam' sweet cherry fruit in the presence and absence of short and long microcracks in the cuticle (CM). ES were inspected for microcracks in the CM (and for stomata) by fluorescence microscopy following water uptake experiments. For regression equation describing the relationship between osmotic water permeability and number of stomata, short and long microcracks see Table 1. Short microcracks were shorter than the longest dimension of the underlying epidermal cell, long microcracks were longer.

Table 1. Parameter estimates of multiple linear regression equation expressing the osmotic water uptake permeability $\left(\mathrm{P}_{\mathrm{f}}\right)$ of excised sweet cherry fruit exocarp segments (ES) as a function of the number of stomata (sto), of short ( rack $_{\text {short }}$, length shorter than longest dimension of underlying epidermal cell) and of long microcracks in the cuticle ( crack $_{\text {long, }}$, length longer than longest dimension of underlying epidermal cell). The regression model was of the type: $\mathrm{P}_{\mathrm{f}}\left(\times 10^{-8} \mathrm{~m} \cdot \mathrm{s}^{-1}\right)=\mathrm{B} 0+\mathrm{B} 1 \times \mathrm{crack}_{\text {long }}($ no. per ES $)+\mathrm{B} 2 \times$ $\operatorname{crack}_{\text {short }}$ (no. per ES) $+\mathrm{B} 3 \times$ sto $\left(\right.$ no. per ES). ${ }^{\mathrm{z}}$

\begin{tabular}{lcc}
\hline Parameter & $\begin{array}{c}\text { Parameter } \\
\text { estimate } \pm \text { SE }\end{array}$ & $P$ \\
\hline Intercept (B0) & $1.36 \pm 0.46$ & 0.0041 \\
Long microcrack (B1) & $1.84 \pm 0.09$ & 0.0001 \\
Short microcrack (B2) & $0.04 \pm 0.02$ & 0.0671 \\
Stomata (B3) & $0.22 \pm 0.03$ & 0.001 \\
\hline$z_{\mathrm{n}}=152 \mathrm{ES}, r^{2}=0.751$ & &
\end{tabular}

${ }^{{ }^{n} \mathrm{n}}=152 \mathrm{ES}, r^{2}=0.751$.

\section{Discussion}

Our study provides three important and new observations. First, formation of microcracks was closely related to the onset of stage III of fruit development in all cultivars and all regions of the fruit surface investigated. Second, microcracks were oriented perpendicular to orientation of the underlying epidermal cells. Third, the difference in projected surface area of epidermal cells underlying minus that adjacent to microcracks in the $\mathrm{CM}$ was positively related to length of the cracks.

Analysis of the fracture pattern of the CM in the course of fruit development and information on the role of microcracks in water uptake allows to address the following questions: 1) Why and where does the CM crack first? 2) What are potential consequences of microcracks in the CM?

Characteristics and distribution of Microcracks. The exocarp represents the mechanical backbone of sweet cherry fruit. It comprises epidermal and hypodermal cell layers and CM. Fruit expansion causes tangential stress which in turn generates a compressive radial force normal to the tangential strain (Considine and Brown, 1981). Thus, tangential structures such as periclinal cell walls of the exocarp and CM are under tension, with the outermost layer subjected to the largest tension. The mesocarp is held under compression by the tension generated in the exocarp. The pressure generated by the strained exocarp composite contributes to fruit turgor. Our data indicate that in sweet cherry fruit the CM as part of the exocarp composite also contributes to turgor. First, we obtained a weak, significant, and positive relationship between the projected area of cells below microcracks and length of microcracks indicating that epidermal cells were strained in response to cracking of the CM (Fig. 6). Cracking of the CM apparently resulted in the transfer of stress from the CM to the underlying epidermal cell. Second, we demonstrated earlier that abrading the CM slightly decreased fruit turgor $(-0.22 \mathrm{MPa}$; Knoche et al., 2004). However, this decrease was markedly smaller than that resulting from cutting the epidermal and hypodermal cell layers which essentially eliminated fruit turgor $(-0.67 \mathrm{MPa})$ in mature fruit. Also, we expect it to be even smaller in immature fruit. During maturation sweet cherries soften and tension is gradually transferred from epidermal and hypodermal cell layers to the CM. This process is initiated as early as 30 DAFB in sweet cherry fruit (Kondo and Danjo, 2001) and would result in increasing stress and possibly development of microcracks. These arguments explain why the first cracks occur in and are initially limited to the CM.

Microcracks in the CM on the sweet cherry fruit exocarp occurred more often above periclinal than anticlinal cell walls (72\% vs. $28 \%$, respectively). Microcracks above periclinal cell walls in cheek and stylar end regions mostly were oriented perpendicular, those above anticlinal cell walls mostly parallel to the longest dimension of the underlying epidermal cell. These observations indicate that lack of cell to cell adhesion was not a dominating factor in microscopic cracking of sweet cherry fruit. The higher frequency of failure above periclinal cell walls may be accounted for by a thinner CM possibly resulting from nonuniform CM deposition and/or strain. Alternatively, the structural support of the CM from underlying cell walls may be nonuniform and possibly limiting in periclinal, compared to anticlinal, regions of the cell wall. Stomata or lenticels that act as stress concentrators in grape (Vitis vinifera L.; Brown and Considine, 1982) were not involved in microscopic cracking of sweet cherry fruit, since stomata were only occasionally associated with cracks. The reason for CM 
failure above a particular epidermal cell remains unknown, since epidermal cells underlying cracks did not differ significantly from neighboring or distant cells either in size, orientation, or length/ width ratio. Occasionally (e.g., Fig. 1F) microcracks appeared to form in response to scratches on the fruit surface. Under orchard conditions fruit are subjected to mechanical stress resulting from contact with leaves, branches, neighboring fruit and from agitation during wind, spray application, etc. This stress, however, is a random event that would not be expected to result in preferential orientation of microcracks.

Comparing DeVelopment OF MiCrocracks ACROSS REgIONS AND CULTIVARS. The change in frequency and severity of microcracks with time was remarkably similar for all cultivars and regions investigated. CM remained intact up to $\approx 43$ DAFB. Thereafter, frequency and severity markedly increased. The beginning of development of microcracks corresponded closely to the onset of stage III of fruit growth in the four cultivars that is characterized by a rapid increase in fruit mass and hence, surface area (Knoche et al., 2004). In our earlier study we demonstrated that stage III development proceeds in the absence of CM deposition thereby causing significant elastic and plastic strain of the CM (Knoche et al., 2004). In the four cultivars investigated elastic strain of the CM was detected at about 43 DAFB (see arrows in Figs. 2A and $3 \mathrm{~A}-\mathrm{C}$ ). Elastic strain causes stress in the $\mathrm{CM}$ and stress, in turn, could result in failure. Since the data from this and our previous study are directly comparable, it may be speculated that development of microcracks in the CM is related to and possibly caused by the strain of the CM during fruit growth. This hypothesis is also supported by the preferential orientation of microcracks perpendicular to the longest dimension of underlying cells (Fig. 4B).

It is interesting to note, that frequency and severity of microcracks differed between regions. Microcracks in the $\mathrm{CM}$ were more frequent and more severe in pedicel cavity and stylar scar regions than in suture or cheek regions (Figs. 2-3; Sekse, 1995). Several factors may account for this observation. First, curvature of the fruit surface is largest in stylar scar and pedicel cavity regions where, based on theoretical considerations, stress would be greatest (Considine and Brown, 1981). Second, stylar scar and pedicel may represent less extensible domains in the fruit surface that restrict strain in their immediate vicinity, thereby causing stress concentration in adjacent regions (Brown and Considine, 1982). Third, stylar scar and pedicel cavity regions are characterized by long periods of surface wetness that could result in localized water uptake and/or altered mechanical properties of the CM (Petracek and Bukovac, 1995; Wiedemann and Neinhuis, 1998). Tukey (1969) reported that exposing developing apple [Malus $\times$ sylvestris (L.) Mill. var. domestica (Borkh.) Mansf.] fruit to high humidity resulted in severe russeting of fruit. Russeting is preceded by formation of microcracks in the CM.

Potential consequences of Microcracks in the CM. Microcracks in the CM may predispose sweet cherry fruit to raininduced macroscopic fruit cracking. First, microcracks serve as high flux pathways for water transport bypassing the penetration barrier (Fig. 7). Water uptake along this route occurs by viscous flow, which is far more rapid than diffusion through an intact CM. Unfortunately, regions that were most prone to microcracking of the CM are those with prolonged periods of surface wetness following rain-fall.

Second, microcracks in the CM weaken the entire exocarp by promoting crack extension and focusing of stress in a particular region. The weak, albeit significant positive relationship between the projected area of cells underlying microcracks and length of microcracks suggests that failure of the CM increases the strain of underlying epidermal cell. The stress in the CM released upon failure is transferred to underlying epidermal tissue. As length of microcracks increases for example due to water uptake into the fruit, more and more stress is transferred from the CM to the epidermal system. This interpretation is consistent with the observation that fruit cracking began at a point along a microcrack and progressed along its length (Glenn and Poovaiah, 1989). Failure of the exocarp and subsequently, the entire fruit, would occur when the yield point of epidermal tissue is exceeded. The yield point, in turn, will depend on many factors, including the mechanical constitution of the fruit as affected by the number of hypodermal cell layers, thickness and mechanical properties of epidermal and hypodermal cell walls (Belmans et al., 1990), degree of fruit softening during maturation (Kondo and Danjo, 2001), strain rates, fruit turgor, presence of surface moisture, and cultural factors like water supply to the tree as affected by rootstock, rain shelters, or irrigation regimes (Hovland and Sekse, 2003; Sekse, 1995). These factors may also account for the absence of a clear relationship between cracking susceptibility of the four cultivars as rated in cultivar descriptions (Bundessortenamt, 1997; Christensen, 1996) and the frequency or severity of microcracks in the CM as observed in the present study.

Third, Hovland and Sekse (2003) reported close positive relationships within cultivars between cracking indices determined in incubation assays and extent of the macroscopically detectable concentric ring cracking in the stylar end region of the fruit. The microcracks described in our study were also oriented tangentially to the stylar scar and, based on the observations of Glenn and Poovaiah (1989), would be expected to develop into macroscopically visible concentric ring cracks described by Hovland and Sekse (2003). Also, microcracks impair the barrier function of the CM to invasion with microorganisms (Glenn and Poovaiah, 1989). For example, cuticular cracks promoted postharvest fruit rot in sweet cherry (Borve et al., 2000) and similar effects are expected preharvest. These detrimental effects of cuticular cracks are aggravated by the apparent absence of repair mechanisms such as periderm formation during stage III of sweet cherry fruit development.

In summary, from our data it appears likely that microcracks in the CM are a general characteristic of the sweet cherry fruit surface at maturity. These microcracks develop during stage III, when fruit increase in mass and surface area within a short period of time. Most of these cracks were orientated perpendicular to the underlying epidermal cells. This observation and the remarkable coincidence between development of microcracks (this paper) and strain of the CM (Knoche et al., 2004) suggest that strain of the epidermal system during stage III development is an important factor in "microcracking" of the CM. Since microcracks in the CM may predispose fruit to the well known rain-induced macroscopic cracking (Glenn and Poovaiah, 1989; Hovland and Sekse, 2003; Sekse, 1995), the relationship between fruit growth, i.e., total, elastic or plastic strains of the CM (Knoche et al., 2004) and development of microcracks merits a critical analysis. This analysis can now be performed, since cracking (this paper) and strain data (Knoche et al., 2004) are available for the same batch of fruit.

\section{Literature Cited}

Andersen, P.C. and D.G. Richardson. 1982. A rapid method to estimate fruit water status with special reference to rain cracking of sweet cherries. J. Amer. Soc. Hort. Sci. 107:441-444. 
Belmans, K., J. Keulemans, T. Debarsy, and R. Bronchart. 1990. Influence of sweet cherry epidermal characters on the susceptibility to fruit cracking. Proc. XXIII Intl. Hort. Congr., 1990, p. 637.

Beyer, M. and M. Knoche. 2002. Studies on water transport through the sweet cherry fruit surface: V. Conductance for water uptake. J. Amer. Soc. Hort. Sci. 127:325-332.

Borve, J., L. Sekse, and A. Stensvand. 2000. Cuticular fractures promote postharvest fruit rot in sweet cherries. Plant Dis. 84:1180-1184.

Brown, K. and J. Considine. 1982. Physical aspects of fruit growthStress distribution around lenticels. Plant Physiol. 69:585-590.

Bundessortenamt, 1997. Beschreibende Sortenliste Steinobst 1997. Landbuch Verlagsgesellschaft mbH, Hannover, Germany, p. 56-58.

Christensen, J.V. 1996. Rain-induced cracking of sweet cherries: Its causes and prevention, p. 297-327. In: A.D. Webster and N.E. Looney (eds.). Cherries. CAB Intl., Wallingford, U.K.

Considine J. and K. Brown. 1981. Physical aspects of fruit growthTheoretical analysis of distribution of surface growth forces in fruit in relation to cracking and splitting. Plant Physiol. 68:371-376.

Considine, J.A. and P.E. Kriedemann. 1972. Fruit splitting in grapes. Determination of the critical turgor pressure. Austral. J. Agr. Res. 23:17-24.

Glenn, G.M. and B.W. Poovaiah. 1989. Cuticular properties and postharvest calcium applications influence cracking of sweet cherries. J. Amer. Soc. Hort. Sci. 114:781-788.

House, C.R. 1974. Water transport in cells and tissues. Edward Arnold, London.

Hovland, K.L. and L. Sekse. 2003. The development of cuticular fractures in fruits of sweet cherries (Prunus avium L.) can vary with cultivar and rootstock. J. Amer. Pomol. Soc. 57:58-62.

Knoche, M., M. Beyer, S. Peschel, B. Oparlakov, and M.J. Bukovac. 2004. Changes in strain and deposition of cuticle in developing sweet cherry fruit. Physiol. Plant. 120:667-677.

Knoche, M., S. Peschel, M. Hinz, and M.J. Bukovac. 2000. Studies on water transport through the sweet cherry fruit surface: Characterizing conductance of the cuticular membrane using pericarp segments. Planta 212:127-135.

Knoche, M., S. Peschel, M. Hinz, and M.J. Bukovac. 2001. Studies on water transport through the sweet cherry fruit surface: II. Conductance of the cuticle in relation to fruit development. Planta 213:927-936.

Knoche, M., H. Tamura, and M.J. Bukovac. 1991. Stability and performance of the organosilicone surfactant L-77: Effect of $\mathrm{pH}$, temperature and concentration. J. Agr. Food Chem. 39:202-206.

Kondo, S. and C. Danjo. 2001. Cell wall polysaccharide metabolism during fruit development in sweet cherry 'Satohnishiki' as affected by gibberellic acid. J. Jpn. Soc. Hort. Sci. 70:178-184.

Landespflanzenschutzamt Sachsen-Anhalt (2000). Pflanzenschutzempfehlungen des amtlichen Pflanzenschutzdienstes des Landes SachsenAnhalt. Landespflanzenschutzamt Sachsen-Anhalt, Germany.

Landespflanzenschutzamt Sachsen-Anhalt (2003). Pflanzenschutzempfehlungen des amtlichen Pflanzenschutzdienstes des Landes SachsenAnhalt. Landespflanzenschutzamt Sachsen-Anhalt, Germany.

Nobel, P.S. 1999. Physicochemical and environmental plant physiology. Academic, San Diego.

Petracek, P.D. and M.J. Bukovac. 1995. Rheological properties of enzymatically isolated tomato fruit cuticle. Plant Physiol. 109:675-679.

Schönherr, J. 1982. Resistance of plant surfaces to water loss: Transport properties of cutin, suberin and associated lipids, p. 153-179. In: O.L. Lange, P.S. Nobel, and C.B. Osmond (eds.). Encyclopedia of plant physiology. NS, vol. 12B. Springer, Berlin-Heidelberg-New York.

Sekse, L. 1995. Cuticular fracturing in fruits of sweet cherry (Prunus avium L.) resulting from changing soil water contents. J. Hort. Sci. 70:631-635.

Tukey, L.D. 1969. Observations on the russeting of apples growing in plastic bags. Proc. Amer. Soc. Hort. Sci. 74:30-39.

Wiedemann, P. and C. Neinhuis. 1998. Biomechanics of isolated plant cuticles. Bot. Acta 111:28-34. 